\title{
SISTEM PENDUKUNG KEPUTUSAN UNTUK MENENTUKAN KUALITAS STASIUN TELEVISI SEBAGAI KONSUMSI TERBAIK BAGI MASYARAKAT DENGAN MENGGUNAKAN METODE AHP
}

\author{
Raja Tama Andriagus \\ Sekolah Tinggi Manajemen Informatika Komputer Royal Kisaran, Asahan
}

tamtamma@ymail.com

\begin{abstract}
Abstrak - Stasiun televisi adalah sebuah teknologi atau media komunikasi yang menampilkan siaran baik audio dan visual, baik yang hitam putih maupun yang berwarna (full color). Banyaknya stasiun televisi saat ini membuat persaingan ketat antara stasiun televisi untuk berinovasi dalam membuat siaran-siaran yang menarik perhatian masyarakat guna mendapat rating tertingg. Namun sering kali karena ingin mengejar rating, banyak stasiun televisi yang kurang memperdulikan mutu dari siaran yang ditampilkannya. Sistem pendukung keputusan merupakan sistem yang dapat digunakan sebagai alat bantu untuk menentukan kualitas stasiun televisi dalam menampilkan siarannya. Analisa data dilakukan dengan cara membandingkan antara stasiun televisi yang ada di Indonesia, yaitu penilaian diambil berdasarkan kadar edukstif, inovatif, dan sumber daya manusia (kru televisi) yang terdapat dimasing-masing stasiun televisi. Hasil dari analisa metode AHP ini menjadi kesimpulan yang membantu masyarakat untuk mengetahui stasiun televisi yang terbaik sebagai konsumsi publik yang cenderung membutuhkan informasi, pengetahuan dan hiburan.
\end{abstract}

Kata kunci - AHP, Stasiun Televisi, Sistem Pendukung Keputusan

Abstract - Television stations are a technology or communication media featuring both audio and visual broadcasts, both black and white (full color). The number of television stations today is making a tough competition between television stations to innovate in making the broadcasts that attract the attention of the public to get the highest rating. But often because they want to pursue the rating, many television stations that do not care about the quality of the broadcasts that appear. Decision support system is a system that can be used as a tool to determine the quality of television stations in displaying the broadcast Data analysis is done by comparing between television stations in Indonesia, that is assessment based on educational, innovative, and human resource (television crew) in each television station. The result of the AHP method analysis is a conclusion that helps the public to know the best television stations as public consumption that tends to require information, knowledge and entertainment.

Keyword - AHP, Television Station, Decision Support System

$\begin{array}{ccc}\text { I. } & \text { PENDAHULUAN } & \text { masyarakat, mulai dari masyarakat lapisan atas, tengah } \\ \text { Pada saat ini media massa menjadi suatu dan bawah. Kebutuhan tersebut seiring dengan } \\ \text { kebutuhan yang mendasar pada seluruh lapisan perkembangan teknologi sekarang ini. Stasiun televisi }\end{array}$


merupakan media massa yang menghiasi televisi dalam menyajikan siaran-siaran untuk menarik perhatian masyarakat. Dengan adanya stasiun televisi, manusia dapat menikmati acara-acara yang dapat menghibur, menginformasikan serta menambah pengetahuan.

Dewasa ini rumah produksi ingin membuat acara berbiaya rendah tapi laku keras. Orientasi komersial jarang jadi prioritas ketimbang kualitas acara. Karenanya tidak sedikit stasiun televisi yang menayangkan acara-acara tanpa kualitas bahkan cenderung kepada hal negatif yang tidak pantas untuk dipertontonkan. Jadilah kemudian lingkaran setan yang susah diputus. Produser membuat acara berdasarkan rating. Rating dibuat karena basis penonton, namun bukannya berfikir bagaimana membuat acara yang berkualitas tapi tetap digemari, para produser stasiun televisi seolah-olah telah dibutakan oleh kilaunya popularitas. Padahal ada banyak manusia yang menjadi korban dari sebuah siaran televisi, khususnya para anak-anak dan remaja yang sering menjadi korban utama dari buruknya media.

Unsur kekerasan dan adegan pacaran dalam sebuah siaran dapat memicu prilaku negatif penontonnya, dalam aspek kognitif, afektif, dan konatif. Siaran televisi mengubah gaya hidup para remaja di Indonesia, pola hidup kebarat-baratan menjadi tren remaja saat ini, bahkan tidak sedikit muda mudi Indonesia yang menganggap seks sebelum menikah adalah biasa dan yang tidak tahu dengan hal itu dianggap sebagai orang kuno. Hal ini tentu saja sangat jauh dari nilai-nilai budaya Indonesia.

Dengan adanya metode AHP dapat dilakukan penelitian tentang baik tidaknya suatu stasiun televisi sebagai tontonan yang dapat dijadikan panutan masyarakat khususnya para muda mudi bangsa. Tentunya analisa dilakukan berdasarkan kualitas acara yang ditayangkan. Dan hal ini nantinya juga dapat membantu negri ini dalam perbaikan moral generasi muda yang cemerlang.

\section{A. $\quad$ Sistem Pendukung Keputusan (Decision Support system)}

Sistem pendukung keputusan (SPK) atau Decision support system (DSS) merupakan suatu sistem interaktif yang membantu pengambilan keputusan melalui penggunaan data dan model-model keputusan untuk memecahkan masalah-masalah yang sifatnya semi terstruktur dan tidak terstruktur (Daihani, 2001). Penyelesaian Sistem Pendukung Keputusan dapat dilakukan dengan banyak metode tergantung pada banyaknya kriteria. Untuk pengambilan keputusan dengan 1 kriteria /single objective decision making dapat dilakukan dengan metode decision tree dan influence diagram. Sedangkan untuk pengambilan keputusan dengan banyak kriteria/ multiple attribute decision making dapat menggunakan banyak metode multiple attribute utility theory, analytical hierarchy process, elimination and choice translating reality methods, the preference ranking organization methods for enrichment evaluation, dan other multiple attribute decision making. Metode MADM yang paling banyak digunakan adalah AHP (Pirdashti, 2009).

\section{B. Pengertian Stasiun Televisi}

Stasiun televisi merupakan salah satu media massa yang menyediakan acara-acara dan menjadi pandang sekaligus media pendengar (audio-visual), yang dimana orang tidak hanya memandang gambar yang ditayangkan televisi, tetapi sekaligus mendengar atau mnerima narasi dari gambar tersebut. (Adi Badjuri, 2010). Sedangkan menurut Ilham Z, (2010:255) Stasiun televisi adalah media yang menyajikan siaran berupa hiburan maupun 
pengetahuan yang sedemikian rupa telah disusun oleh tim kreatif dan ditujukan kepada khayalak banyak.

\section{Pengertian Analytical Hierarchy Process (AHP)}

Prinsip kerja AHP adalah penyederhanaan suatu persoalan kompleks yang tidak terstruktur menjadi bagian-bagiannya, serta menata dalam suatu hirarki. Kemudian tingkat kepentingan setiap variabel diberi nilai numerik secara subjektif tentang arti penting variabel tersebut secara relatif dibandingkan dengan variabel lain. Dari berbagai pertimbangan tersebut kemudian dilakukan sintesa untuk menetapkan variabel yang memiliki prioritas tinggi dan berperan untuk mempengaruhi hasil pada sistem tersebut. (Suryadi, 2001)

D. Ciri-ciri dan Karakteristik Sistem Pendukung Keputusan

1. SPK ditujukan untuk membantu keputusankeputusan yang kurang terstruktur dan umumnya dihadapi oleh para manajer yang berada di tingkat puncak.

2. SPK merupakan gabungan antara kumpulan model kualitatif dan kumpulan data.

3. SPK memiliki fasilitas interaktif yang dapat mempermudah hubungan antara manusia dengan komputer.

4. SPK bersifat luwes dan dapat menyesuaikan dengan perubahan-perubahan yang terjadi.

\section{E. Langkah-langkah metode AHP}

1. Mendefinisikan Masalah

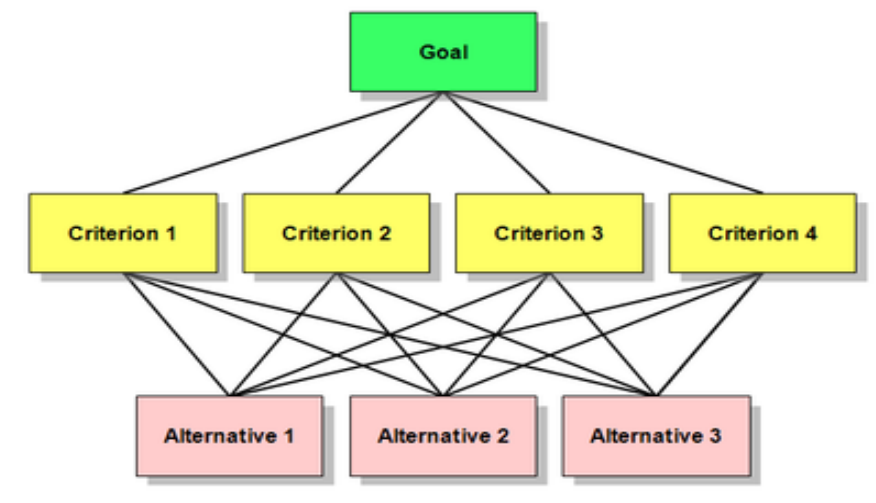

Gambar 1 Hierarki pendefenisian masalah

2. Menetapkan Prioritas Elemen

a. Langkah pertama dalam menentukan prioritas elemen yaitu dengan membuat perbandingan berpasangan, yaitu membandingkan elemen secara berpasangan sesuai kriteria yang diberikan.

b. Matriks perbandingan berpasangan diisi menggunakan bilangan untuk mempresentasikan kepentingan relatif dari suatu elemen terhadap elemen lainnya.

3. Sintesis

Untuk memperoleh prioritas secara keseluruhan maka pertimbanganpertimbangan terhadap perbandingan berpasangan perlu disintesis. Dalam langkah ini, hal-hal yang dilakukan adalah :

a. Menjumlahkan nilai-nilai dari setiap kolom pada matriks

b. Membagi setiap nilai dari kolom dengan total kolom yang bersangkutan untuk memperoleh normalisasi matriks

c. Menjumlahkan nilai-nilai dari setiap baris dan membaginya dengan jumlah elemen untuk mendapatkan nilai rata-rata 
4. Mengukur Konsistensi

Dalam pembuatan keputusan, tingkat konsistensi penting untuk diperhatikan karena kita tidak menginginkan keputusan berdasarkan pertimbangan dengan konsistensi yang rendah. Hal-hal yang dilakukan dalam langkah ini adalah:

1. Mengalikan setiap nilai pada kolom pertama dengan prioritas relatif elemen pertama, nilai pada elemen kedua dengan prioritas relatif elemen kedua, dan seterusnya.

2. Jumlahkan setiap baris

3. Hasil dari penjumlahan baris dibagi elemen prioritas relatif yang bersangkutan

4. Jumlahkan hasil bagi diatas dengan banyaknya elemen yang ada hasilnya disebut 1 maks.

5. Hitung indeks konsistensi/ Consistency Index

(CI) dengan rumus:

$\mathrm{CI}=($ lamda maks-n) $/ \mathrm{n}-1$, Dimana $\mathrm{n}=$ banyaknya elemen

6. Hitung rasio konsistensi / Consistency Ratio

(CR) dengan rumus: $\mathrm{CR}=\mathrm{CI} / \mathrm{IR}$

$\mathrm{CR}=$ Consistency Ratio

$\mathrm{CI}=$ Consistency Index

IR = Index Random

7. Memeriksa konsistensi hirarki tabel index random

Tabel 1 Index random konsistensi hirarki

\begin{tabular}{|l|l|l|l|l|l|l|l|l|l|l|l|l|l|l|l|}
\hline$n$ & 1 & 2 & 3 & 4 & 5 & 6 & 7 & 8 & 9 & 10 & 11 & 12 & 13 & 14 & 15 \\
\hline
\end{tabular}

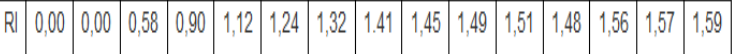

8. Perhitungan untuk menentukan tujuan

Setelah perhitungan CR sudah diterima/berhasil maka perhitungan dilanjutkan untuk menentukan tujuan akhir, yaitu perhitungan sebagai berikut :

Hasil1 $=($ Nilai Kriteria $1 *$ Prioritas Kriteria 1$)+$ (Nilai Kriteria2 * Prioritas Kriteria2 ) $+\ldots$ sampai kriteria-n+Prioritas Kriteria-n.
Hasil2 $=($ Nilai Kriteria2 $*$ Prioritas Kriteria1 $)+$ (Nilai Kriteria2 * Prioritas Kriteria2 ) $+\ldots$ sampai kriteria-n.

Hasil-n $=($ Nilai Kriteria- $n *$ Prioritas Kriteria1 $)$ $+($ Nilai Kriteria-n $*$ Prioritas Kriteria2) $+\ldots$ sampai kriteria-n.

Hasil akhir merupakan perbandingan dari hasilhasil yang telah dihitung, dengan membandingkan semua hasil, maka didapat hasil tertinggi dan hasil ini merupakan keputusan hasil akhir yang dipilih.

\section{METODOLOGI PENELITIAN}

\section{A. Jenis dan Sumber Data}

Jenis data yang dikumpulkan dan dianalisis adalah bersumber dari standarisasi kelayakan acara televisi menurut Komisi Penyiaran Indonesia (KPI), dan data lainnya.

\section{B. Lokasi Penelitian}

Penelitian ini dilakukan di daerah Kab. Asahan yaitu dengan mewawancarai masyarakat setempat yang menjadi konsumsi siaran televisi dan melalui data standarisasi kelayakan acara televisi menurut Komisi Penyiaran Indonesia (KPI)

\section{Populasi dan Sampel Penelitian}

Populasi penelitian ini adalah seluruh masyarakat setempat yang berdomisili di Kab. Asahan yang menjadi konsumsi dan sasaran utama oleh stasiun televisi, dan pada akhirnya dapat disimpulkan bahwa televisi sudah menjadi kebutuhan primer semua masyarakat. Dalam pemilihan kualitas stasiun televisi ini terdapat beberapa kriteria yang digunakan yaitu : Edukatif, Inovatif, dan SDM. Sesuai dengan kebutuhan dalam penelitian ini langkah-langkah penelitiannya adalah sebagai berikut : 
a. Menentukan stasiun televisi dengan kriteriakriterianya adalah edukatif, inovatif, SDM sebagai standart utama kualitas sebuah stasiun televisi. Dan alternatif di dapatlah stasiun televisi yang ada di Indonesia, yaitu : Indosiar, Antv, MNC Media, Sctv, Trans, dan Net tv.

b. Menentukan jenis-jenis kriteria yang akan menjadi persyaratan pemilihan stasiun televisi dan menyusun kriteria-kriteria tersebut dalam bentuk matriks berpasangan.

\section{HASIL DAN PEMBAHASAN}

A. Proses implementasi Analytical Hierarchy Process (AHP)

Implementasi AHP dimulai dari membandingkan antara Kriteria. Berikut adalah tabel hasil perbandingan kriteria dengan kriteria lainnya.

Tabel 2 Perbandingan kriteria

\begin{tabular}{|c|c|c|c|c|c|c|c|c|}
\hline & Edukatif & Inovatif & SDM & \multicolumn{3}{|c|}{ Bagi elemen tiap kolom } & jumlah & rata-rata \\
\hline Edukatif & 1 & 0,500 & 0,167 & 0,1111 & 0,1111 & 0,1111 & 0,3333 & 0,1111 \\
\hline Inovatif & 2 & 1 & 0,333 & 0,2222 & 0,2222 & 0,2222 & 0,6667 & 0,2222 \\
\hline SDM & 6 & 3 & 1 & 0,6667 & 0,6667 & 0,6667 & 2,0000 & 0,6667 \\
\hline & 9,000 & 4,500 & 1,500 & & & & & 1 \\
\hline
\end{tabular}

Hasil pemrosesan perbadingan kriteri iatas didapatkan bahwa didapatkan nilai CR 0,00 dengan demikian dinyatakan konsistensi karena nilai Consistency Ratio ( CR ) lebih kecil dari $10 \%$. Selanjutnya membandingkan antara alternatif pada kriteria edukatif.

Tabel 3. Perbandingan alternatif terhadap kriteria edukatif

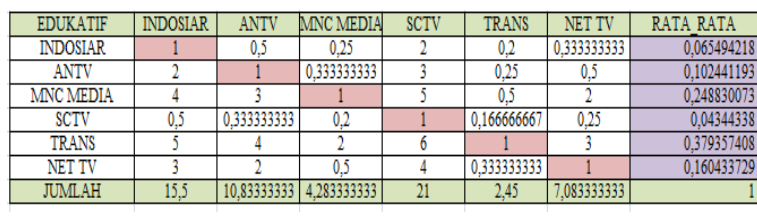

Selanjutnya adalah menentukan matriks perbandingan yang membandingkan antara alternatif pada kriteria inovatif.

Tabel 4. Perbandingan alternatif terhadap kriteria

\begin{tabular}{|c|c|c|c|c|c|c|r|}
\hline NOVATIF & INDOSIAR & ANTV & MNCMEDIA & SCTV & TRANS & NET TV & RATA RATA \\
\hline INDOSIAR & 1 & 0,3333333333 & 0,25 & 0,5 & 0,166666667 & 0,2 & 0,04344338 \\
\hline ANTV & 3 & 1 & 0,5 & 2 & 0,25 & 0,3333333333 & 0,102441193 \\
\hline MNCMEDIA & 4 & 2 & 1 & 3 & 0,3333333333 & 0,5 & 0,160433729 \\
\hline SCTV & 2 & 0,5 & 0,3333333333 & 1 & 0,2 & 0,25 & 0,065494218 \\
\hline TRANS & 6 & 4 & 3 & 5 & 1 & 2 & 0,379357408 \\
\hline NET TV & 5 & 3 & 2 & 4 & 0,5 & 1 & 0,248830073 \\
\hline JMLAH & 21 & 10,83333333 & 7,0833333333 & 15,5 & 2,45 & 4,2833333333 & 1 \\
\hline
\end{tabular}

Selanjutnya adalah menentukan matriks perbandingan yang membandingkan antara alternatif pada kriteria SDM.

Tabel 5. Perbandingan alternatif terhadap kriteria SDM

\begin{tabular}{|c|c|c|c|c|c|c|r|}
\hline SDM & NDOSIAR & ANTV & MNC MEDIA & SCTV & TRANS & NET TV & \multicolumn{1}{c|}{ RATA_RATA } \\
\hline NDOSIAR & 1 & 0,5 & 0,25 & 0,333333333 & 0,16666667 & 0,2 & 0,04344338 \\
\hline ANTV & 2 & 1 & 0,33333333333 & 0,5 & 0,2 & 0,25 & 0,065494218 \\
\hline MNC MEDIA & 4 & 3 & 1 & 2 & 0,333333333 & 0,5 & 0,160433729 \\
\hline SCTV & 3 & 2 & 0,5 & 1 & 0,25 & 0,3333333333 & 0,102441193 \\
\hline TRANS & 6 & 5 & 3 & 4 & 1 & 2 & 0,379357408 \\
\hline NET TV & 5 & 4 & 2 & 3 & 0,5 & 1 & 0,248330073 \\
\hline TUMLAH & 21 & 15,5 & 7,0833333333 & 10,833333333 & 2,45 & 4,2833333333 & 1 \\
\hline
\end{tabular}

Langkah selanjutnya adalah menentukan nilai sintesis sebagai acuan dalam menentukan prangkingan.

Tabel 8 Perangkingan

\begin{tabular}{|l|r|c|}
\hline \multicolumn{1}{|c|}{ Alternative } & \multicolumn{1}{c|}{ Hasil Sistesis } & rangking \\
\hline INDOSIAR & 0,045893473 & 6 \\
\hline ANTV & 0,077809876 & 5 \\
\hline MNC MEDIA & 0,170255545 & 3 \\
\hline SCTV & 0,087675441 & 4 \\
\hline TRANS & 0,379357408 & 1 \\
\hline NET TV & 0,239008257 & 2 \\
\hline
\end{tabular}

Dari hasil perangkingan yang dihasilakan, maka didapatkan bahwa Trans merupakan stasiun televisi yang terpilih sebagai yang terbaik. Hal ini tentunya harus dilakukan pengujian menggunakan aplikasi super decission untuk memastikan proses yang dilakukan berjalan dengan benar.

\section{B. Pengujian melalui aplikasi super decission \\ Pada tahapan ini dilakukan pengujian dengan} menggukan aplikasi super decission untuk membandingkan hasil yang didapat melalui proses 
AHP. Berikut adalah hasil pengolahan melalui aplikasi super decission.

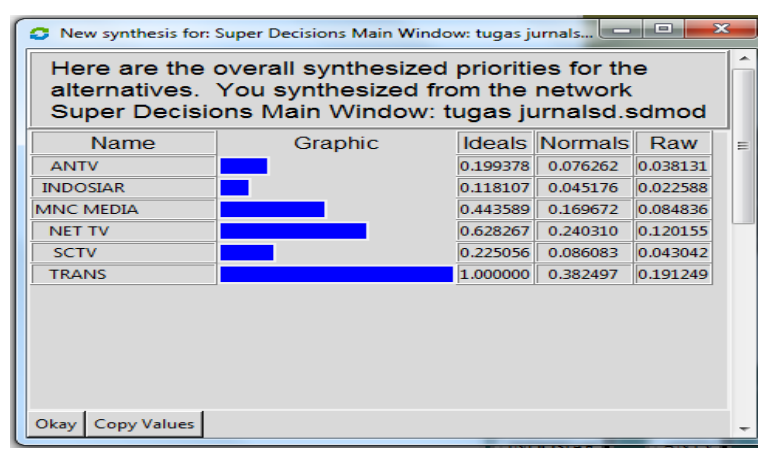

Gambar 2 Perangkingan berdasarkan super decission

\section{KESIMPULAN}

1. Penggunaan metode AHP tepat digunakan untuk menyelesaikan permasalahan Multiple Attribute Decision Making dalam hal ini menentukan kualitas stasiun televisi yang terbaik untuk dikonsumsi masyarakat.

2. Stasiun televisi yang berkualitas dapat diketahui dari program-program acara yang disiarkannya mengandung nilai positif atau negatif bila ditonton oleh masyarakat.

3. Dari hasil penelitian, dapat diketahui bahwa stasiun televisi berkualitas terbaik untuk dikonsumsi oleh masyarakat adalah trans, yaitu yang terdiri dari trans 7 dan trans tv.

4. Stasiun televisi trans dikatakan menjadi yang berkualitas terbaik dikarenakan programprogam acara yang disiarkannya mengandung unsur pendidikan dari program acara laptop siunyil, on the spot, tau gak sih, bolang, dll. Dan selalu berinovasi dalam menayangkan acara, ini semua dapat diketahui dari acaraacaranya yang selalu bervariasi dan tidak monoton. Dan semua itu tidak lain karena ideide cerdas dari para tim kreatifnya (SDM).

\section{DAFTAR PUSTAKA}

[1] Adi Badjuri, (2010). Manfaat dan pengaruh Televisi bagi Masyarakat Indonesia. Jakarta:Penerbit Andi.

[2] Alonso, J. A., dan Lamata, M. T., 2006, Concistency In The Analytical Hierarchy Process:

A New Approach, International Journal of Uncertainty, no 4, volume 14, hal.445-459.

[3] Daihani, D.Umar. (2001). Komputerisasi

Pengambilan Keputusan. Jakarta:PT Elexmedia Komputindo

[4] Ilham Z, (2010:255). Jurnal.pdf Pengaruh Televisi bagi Generasi Bangsa. Di ambil dari: http// Ilham-azhar.blogspot.com pada 21 Maret 2017 pukul 13.00 .

[5] Pirdashti, M., Ghadi, A., Mohammadi M., \& Shojatalab G. (2009). Sistem Pendukung Keputusan. Bandung: PT Remaja Rosdakarya. 